\title{
El rol del idIoTa en la intervención en Diseño: una aproximación a partir del caso de la "casa inteligente"
}

DESIGN RESEARCH: THE IDIOT'S ROLE IN THE 'SMART' HOME

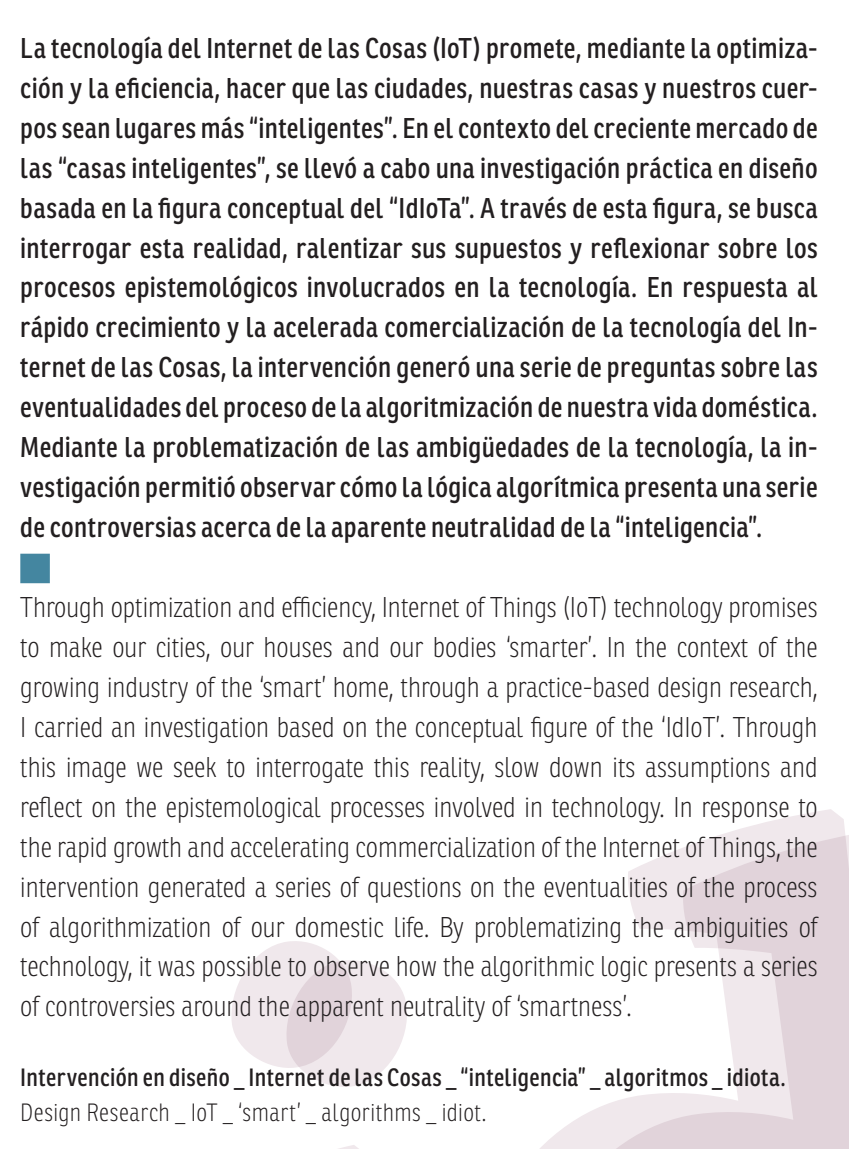

LOGICA ALGORITMICA: EL INTERNET DE LAS COSAS

El gran avance de la tecnologia y la reducción en el

che delancho de banda de Internet (network capabilities), han de productos con la tecro éćcada en un rápido desarrollo

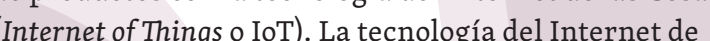
( aplicaciones industriales, migrando posteriormente hacia nuestras ciudades, casas y hacia nuestros propios cuerpos. EI Internet de las Cosas se puede describir como la tecnologia detrás de objetos conectados a Internet que son identificables, programables y capaces de conectarse (costos objetos

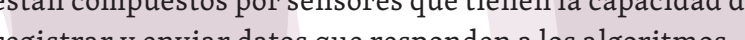

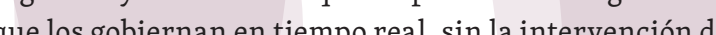

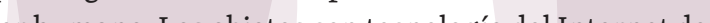
las Cosas usulmente incorporan un amplio espectro de sensores de gran precisión. En este proceso algorítmico los datos son extraidos y recombinados con fuentes de bases de datos (databases). Las decisiones "inteligentes" atomatizadas que realizan los objetos "inteligentes" se basan particularmente en dos fenómenos actuales Artificial (IA): Big Data y Machine Learning.

Dado el avance de la tecnología IoT, el impacto de la lógica algorítmica no debe ser subestimado; de hecho, se prevé que el Internet de las Cosas será el mayor mercado de disposititios en el mundo (Greenough, 2014). En terminos estadsticos "cosas" conectadas estarán en uso en 2020, mientras que Cisco proyecta que, para el mismo año, 50 mil millones de objetos estarán conectados (Evans, 2011). La disparidad de las cifras refleja la rapidez con que el área está emergiendo, así como incertidumbre implícita en esa velocidad.

Como resultado de un rápido desarrollo tecnológico

que se suma a las fuerzas del mercado, Internet y su logica
algorítmica se han ido integrando en nuestros espacios y objetto
DELFINA FANTINI VAN DITMAR Royal College of $A$ rt

delfina.fantinienetwork.r.ca.ac

ALGORITHMIC LOGIC: THE INTERNET OF THINGS The great advancement of technology and the reduction In the cost of processors and sensors, as well as the steady increase in network capabilities, have led in the last decade to a rapid development of products with Internet of Things (IOT) gos in the context of industrial applications, migntine the Our cities, homes and to our own bodies. The Internet of things can be described as the technology behind objects connected to the Internet that are identifiable, programmable and capable of connecting (communicate) with other 'smart' objects. These objects are equipped with sensors capable of recording and sending data that responds to the algorithms that govern them in real-time without human intervention. objects with Internet of Things technology usually incorporate a wide spectrum of high-precislon sensors. In his algorth smic process,

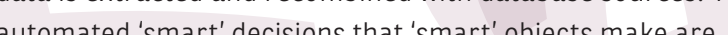
specifically based on two present-day phenomena based on the development of the field of Artificial Intelligence (Al): Big Data and Machine Learning.

Given the advancement of lo technology, the impact of the

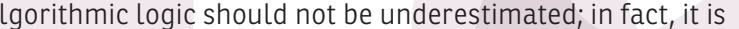
foreseen that Internet of Things will be the world's largest device market (Greenough, 2014). In statistical terms, the firm (2014) estimates that 25 bittion connected 'things' will Jer 50 bic by 2020, white Cisco is projecting that by the same disparity of hesects wit be consected (Evans, 2011). The

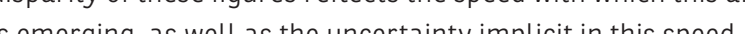
As result of a fast-paced technological development that As resut of a fast-paced techologleal dits jave started to becone integated into the spases a 
circundantes, incorporándose cada vez más a nuestras vidas. Hoy, la industria del Internet de las Cosas ofrece servicios
"inteligentes" que van desde la automatización control monitoreo del dispositivo, hasta el "aprendizaje" y predicción del comportamiento de los usuarios. Ejemplos actuales de la integración entre el Internet de las Cosas y nuestro espac circundante incluyen áreas como la seguridad del hogar, el control de la calefacción, la automatización de la iluminación

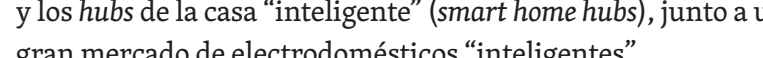

Dentro de la temática contemporánea de la "smartificació de nuestras vidas, se ha planteado una serie de problemas
sobre lo que sería un reduccionismo informático, así como sobre la algoritmización de la vida y la sociedad. La conver del comportamiento humano en datos computacionales mediante el uso de inferencias algorítmicas caracterizadas por una recombinacion de información sobre los usuarios con extensas bases de datos, deja atrás no solo la subjetivida d de quien usa un determinado objeto, sino también los contextos y variables de la vida diaría a partir de los cuales

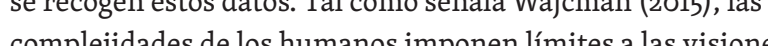
técnicas de la vida doméstica.

La complejidad de la existencia humana está lejos de poder ser traducida a una lógica estadística y numérica “inteligente". Esto es lo que Gillespie llama «la promesa de la objetividad algorítmica: la forma en que el carácter técn imparcialidad» (Gillespie, 2014, pás. 166).

Dado este contexto, como una alternativa al enfoque en desarrollo, eficiencia y optimización propuesto por campos relacionados con la tecnologia del Internet de las Cosas, se generó mediante una investigación en diseño "la propuesta delidota, una reflexion sobre los supuestos, problemss y desafios que presenta la mas en nuestras vidas.

\section{EL VALOR DEL IDIOTA EN LA INTERVENCIÓN EN DISEÑO}

mo una forma de reflexionar sobre (e interrogar a) los efectos del rápido crecimiento de Internet de las Cosas y sus implicancias en nuestras formas de vida. Surge, más especificamente, como método criticocada vez más presente entre algoritmos y sociedda. Para llever esto a cabo, se realizó una investigación a través del diseño esto a cabo, se realizo una investigación a través del diseño
basada en la figura conceptual del IdIoTa, la cual nace de la incorporación del cuestionamiento de la tecnología IoT en la figura conceptual del idiota'

Si bien la investigación en diseño es un término

amplio, aquílo defino como un área de experimentación caracterizada por la apertura a espacios de autorreflexión en el proceso metodologico y por un activo involucramien del investigador. Tal como indica Glanville (2006), la

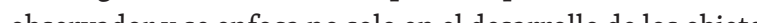
sino también en los procesos. around us, becoming increasingly assimilated into our lives. ( 'learning' and predictiontrol and monitoring of the device, to of the integration between the Internet of Things and our surrounding space include areas like home security, heating control, lighting automatization and smart home hubs, together of 'smart' appliancess.

Within the contemporary theme of 'smartification' of our Lives, a series of issues have been posed about an alleged
informatic reductionism, as well as about the al gorithm of life and society. The conversion of human behaviour into computer data with the use of algorithmic inferences

characterised by a recombination of information on users with large datasets, leaves behind not only the subjectivity of who uses a particular object, but also the contexts and variables of the daily life from where this information is gathered. As pointed out by Wajcman (2015), the complextes of huma impose limits on the technical visions of domestic life. The complexity of human existence is far from the possibility of being translated into a statistical and numerical ' 'smart' logic. This is what Gllespie calls the promise of algorithmic objectivity the way the technical character of the atgorithm is post

Given this context, as an alternative to the development, related with the Internet of Things technology, the "idloT proposal' was generated through design research, a reflection on the assumptions, problems and challenges that the massive introduction of this technology in our lives presents.

\section{THE ROLE OF THE IDIOT IN DESIGN RESEARCH}

The IdloT proposal is born as a way to reflect on (and question) the effects of the rapid growth of the Internet of Things and its implications in our ways of life. It emerges,
more specifically, as a critical-speculative method to analys the implications of the interrelation that exists between

algorithms and society.

To achieve this, a design research work was done based Ont the conceptual figure of the id iot, which is born from the incorporation of a questioning of technology in the conceptual figure of the idio

Although design research is a broad term, I define it here as an area of experimentation characterised by the opening of spaces of self-reflection in the methodotogic process, and by an active involvement of the researcher. As pointed emphasises the role of the observer and focuses not only in development of the objects, but also in the processes.
Así, mediante la figura del idoTa, se buscó generar un levantamiento de información cualitativa que sirviera como en diseño no tiene como principal propossito proporcionar resultados empíricos, sino generar nuevos conocimientos y posibilidades. Para ello se usaron metodologías interventivas y materializadas del área del diseño, así como también ciertos elementos del Critical yel Speculative Design. El primero es problemas potenciales $\mathrm{s}$ repercusiones que caracterizana los avances tecnológicos. Para ello promueve una serie de enfoques alternativos a la funcionalidad de los productos, los que apuntan a exponer y evidenciar problemas tecnológicos en lugar de resolverlos, caracterizándose por el uso de la especulación, las narrativas de ficción, el debate político y, más
ampliamente, el cuestionamiento de la tecnología (Pierce, 2015). Como señala Pierce (2015), desde la introducción de término por Dunne y Raby', lo que se entiende por diseño crítico se ha ampliado a partir del uso que la comuni del diseño ha dado al concepto, y también puede ser

conceptualizado como disent yoscrtico (Post-Critical Design). desplazó hoc el diseño especulativo (Speculative Design) el cual se basa en la idea de que el proyecto de diseño se present a menudo a través de escenarios ficticios (incorporando algín tipo de especulación en el resultado) como una forma de provocar discusiones acerca de un tema.

A pesar de que mi investigación en diseño no se inscribe directamente bajo estos enfoques, utilizo herramientas similares, tales como la especulación, la simulación, el escepticismo y la ficcion, como herramientas para cuestion los supuestos y volver discutibles ciertos temas vinculados

La intervención se basa en un componente idioTico; esto es, no propone soluciones tecnológicas, sino generar

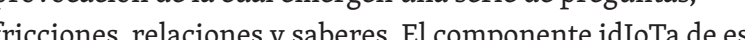
investigación surge al combinar la "figura del idiota" descrita por Stengers (2005) en su propuesta cosmopolítica cos la extensión de esta propuesta teórica realizada por Michael (2012) en el campo de la sociología/diseño, transformando al idiota en una herramienta metodológica.

Tal como sugiere Stengers, el idiota crea un intersticio, «un espacio para pensar»», resultando una figura de gran utilidad para preguntamos «qqué estamos haciendo?» (what are we busy doing?) (2005, pág. 995). Stengers describe esto como «una propuesta para provocar el pensamiento, un qua na de para despertar una conciencia ligeramente diferente de pos problemas y situaciones» (2005, pán. 994). Lo anterio resuena con la estrategia de Glanville (2014b) de "ir más despacio" (slowing down). Como indica Glanville, «si bajas a velocidad, entonces verás matices que normalmente no particular $-\gg$ (2014b, pág. 25).
Thus, through the image of the idloT, we sought to generate a gathering of qualitative information that would serve as a have as main purpose to provide empirical results, but to generate new knowledge and possibilities. For this purpose, we used interventive and materialised methodologies in the area of design, as well as certain elements of Critical Design and Speculative Design. The first one is an area of reflection repercussions that characterise technological advancement For this, it promotes a series of alternative perspectives to the functionality of products, which aim at exposing and evidencing technological problems instead of solving them, characterised by the use of speculation, fictional narratives, political debate and in a broader sense, the questioning of technology (Pierce, 2015). As Pierce (2015) points out, since the introduction of the term by Dunne and Raby', what we understand as Critical Design has expanded due to the use that the community of design has given to the concept, and which can also be conceptualised as PostCrtical Design. With the passing of cime, Dunne and Raby's ow the idea that the design project is frequently presented throun fictional scenarios (incorporating some degree of speculation in the result) as a way of generating discussion about a given issu. Despite that my design research work does not inscribe directly under these approaches, I use similar tools, such as speculation, simulation, scepticism and fiction as tools to question the assumptions and render certain issues related to the 'smart' algorithms arguable.

The intervention is based on an idlotic component; that is, te doesn't propose technological solutions, but to generate a provocation from which a series of questions, frictions, relations research emernes described by Stengers (2005) in his cosmope of the ditot as Wh the extension of this theoretical proposal by Michael (2012) in the field of sociology/design, transforming the idiot into methodological tool.

Just as Stengers suggests, the idiot creates an interstice, a "space to think' resulting in a figure that is of great use to ask describes this as "a proposal to provoke thought, one that requires no other verification than the way in which it is able to 'slow down' reasoning and create an opportunity to arouse a slightly different awareness of the problems and situations" (2005, p. 994). This resonates with Glantile's strategy (2014b) of 'slowing down'. As Glanville indicates, 'I fyou stow things down then you se - slowness has a particular quality of its own -" (2014t, . . 25.

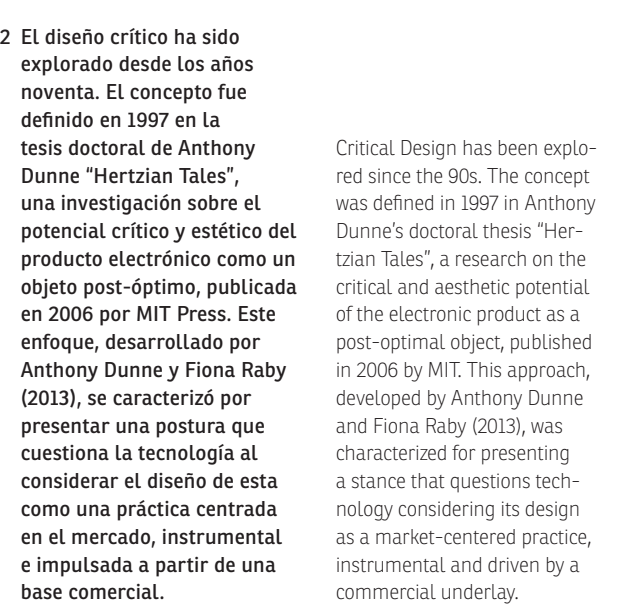




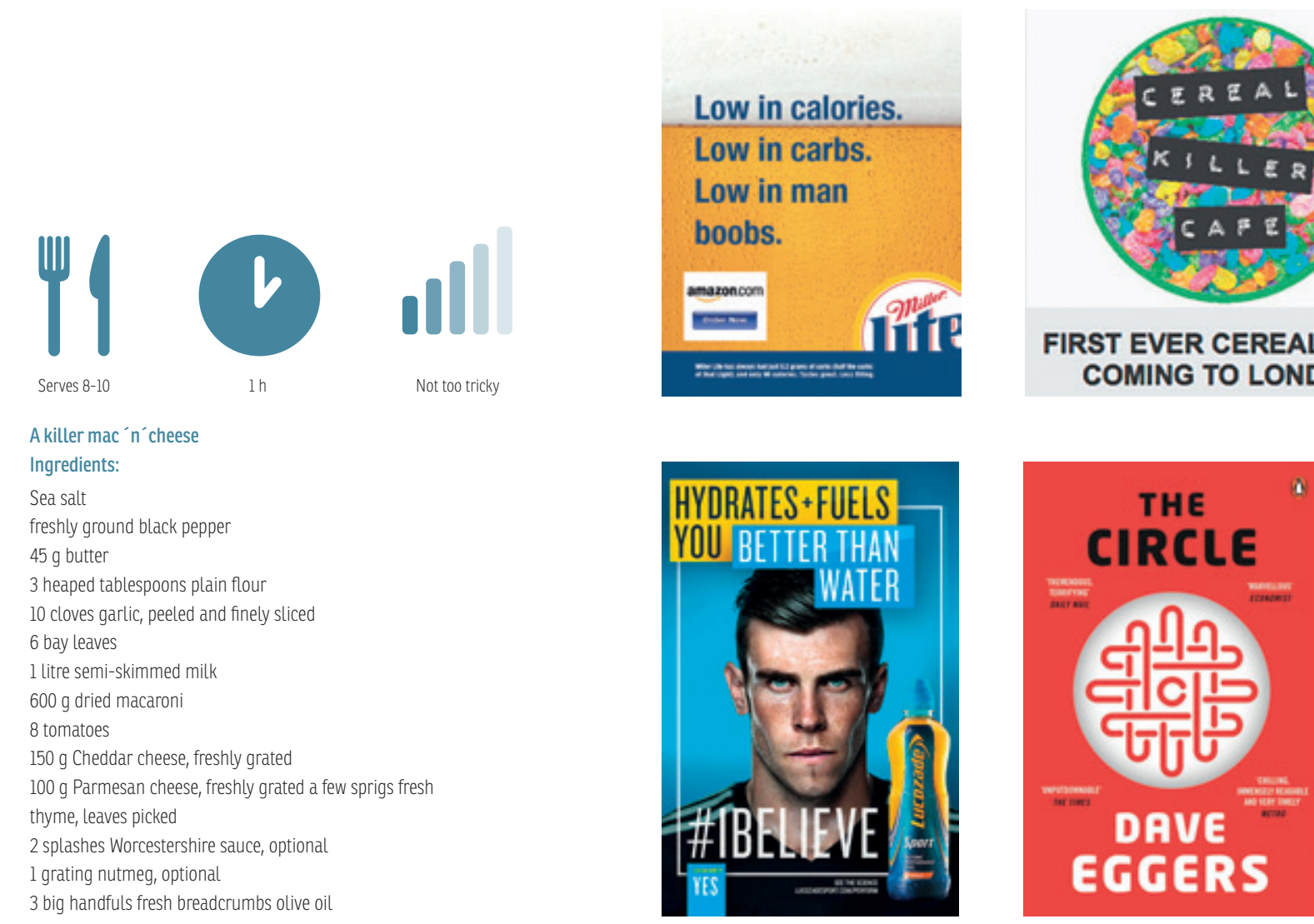

La figura del idiota descrita por Stengers (2005) se basa en el personaje conceptual del idiota planteado por Deleuze (1994), quien a su vez lo toma prestado del príncipe Myshkin
de la novela El Idiota de Dostoievski. En el libro de Dostoievski, de la novela El Idiota de Dostoievski. En el libro de Dostoiev
el idiota y su absurdo sirven como un mecanismo para el idiota y su absurdo sirven como un mecanismo para
revelar y cuestionar la corrupción del mundo y sus siste revelar y cuestionar la corrupción del mundo y sus sistemas de valores. Como senalan Deleuze y Guattari, «el idiota de

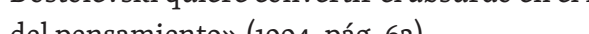

En la presente investigación, la figura del idioTa sirve para detenerse y reffexionar sobre los procesos epistemológicos permitiendo pensar en las posibilidades "impensables" medio de estar constantemente preguntándose iqué estamos haciendo? (what are we busy doing?) o ¿qué pasaría si? Como Stengers (2005) destaca, esto hace que el investigador se encuentre politicamente activo, comprometido y conscien de lo que él conoce de los factores involucrados en la

formulacion del pobera y de bs solociones previstas. La ambición de certidumbre y previsibilildad, junto con las simplificaciones algorimicas, se rlacionan con el concepto de la tendencia de la industria nocnóórica a precisar problom basados en soluciones rápidas y algorítmicas lo que a menudo resulta en arreglar un "no problema". Desde este punto de vista, el idiota presenta una serie de problemas y permite cuestionar la narrativa lineal y objetiva de la "inteligencia” tecnológica.

Como señalan Deleuze y Guattari, «el idiota de Dostoievski quiere convertir el absurdo en el más alto poder del pensamiento» (1994, pág. 62). (20) the technological industry to pinpoint problems based on fast, poblem' From this, perspective, the idiot presents a series

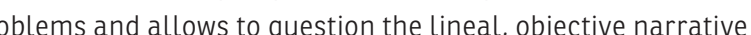
technological 'smartness'.
CONVIRTIÉNDOME EN UN REFRIGERADOR "INTELIGENTE" Con la finalidad de cuestionar la neutralidad de la "inteligencia" algorítmica mediante el uso de la figura
del idloTa, en este caso personificado en un refrigerador "inteligente", simulé personalmente ser un refrigerador conectado a Internet. Elegí como caso de estudio el refrigerador "inteligente", ya que los hábitos alimentarios ilustran, tal vez más que cualquier otra cosa, lo compleja impredecible que es la vida humana. A su vez, la alimentací (a)

Para el estudio decidí utilizar usuarios que ya se estaban cuantificando con dispositivos "inteligentes" seguidores de
actividad (wearables / activity trackers). Estos participantes pueden considerarse como usuarios pioneros (early adopters) de la tecnología del Internet de las Cosas. A su vez, dichos usuarios pueden ser definidos como potenciales consumido dado el potencial interés preexistente en el monitoreo caracterizado por datos agregados, en este caso relacionados

Como metodología para reunir datos y antecedentes de para el estudio se llamaba a los usuarios a ser parte de una investigación de la tecnología del Internet de las Cosas, y se les requería que la entrevista se desarrollara en sus respectivas casas bajo el contexto de una comida. Se les pidió que cocinaran lo que tuvieran en el refrigerador, destacando que no era necesario comprar más ingredientes. Esta configuració experimental se genero a pastral diterés en diseñar una giraba alrededor de los hábitos alimentarios-, sino que

además permitía el acceso a sus refrigeradores.

En cuanto a los métodos de investigación, utilicé dos estrategias para capturar información relevante, la cual luego sería utilizada para elaborar el reporte de un refrigerador "inteligente". Por una parte, grabé la entrevista sobre sus hábitos alimentarios y su actividad física (información cualitativa). Por otra parte, tomé fotograffias del contenido de sus respectivos refrigeradores, lo cual representa datos potencerater "inteligente"

A continuación, a partir de ambas fuentes (contenidos tativa), realicé para cada participante una simulación personalizada de un reporte de un
refrigerador "inteligente" derivado de sus datos personales El reporte fue enviado, sin notificar a los usuarios de antemano, desde la cuenta yoursmartfridge@gmail.com y fue firmado como "Tu Refrigerador Inteligente" ('Your Smart Fridge'). El reporte se escribió en un lenguaje "amigable" (userfriendly), mientras que la fuente y los colores del texto estaban orientados al diseño de interfaz que caracteriza a las aplicaciones (app-oriented). Diferentes compañias

inteligentes (intelligent personal assistants O IPA) con diferentes

As Deleuze and Guattari point out, "Dostoievsky's idiot wants to transform the absurd into the highest power of thought" $(1994$, p. 62).

BECOMING A 'SMART' REFRIGERATOR associated with health and physical activity. but also allowed us access to their refrigerators. de la tecnología IoT del hogar "inteligente" ('smart' home) cualiativiva en l casa de los participantes. En la invitrción

With the purpose of questioning the neutrality of algorithm 'smartness' by using the figure of the idloT, in this case personified in a 'smart' refrigerator, I simulated myself being the 'smart' refrigerator, since eating habits illustrate, perhap better than anything else, how complex and unpredictable human life is. Eating is associated at the same time with psychology, history, culture, personality and budgets. For this study, I decided to choose subjects that were already being quantified with 'smart' wearable activity trackers. Thes participants may be considered as pioneering users, early users may be defined as potential consumers of $10 T$ ' home technology given the potential interest pre-existing in the monitoring characterised by aggregate data, in this case,

As a methodology to gather data and antecedents of the three users to investigate, I decided to conduct a qual itative 'ntervew in the participants' home. In the invitation to the study, the users were called to be part of a research on the internet of Things technology, and they were required that the context of a a take place in their respective homes in the the refrigerator, stressing that it wasn't necessary to buy more from the interest in designing an intimate moment that not on facilitated the interview - which evolved around eating habits -

As to the research methods, I used two strategies to gather relevant information, which would then be used to prepare the the interview on eating habits and physical activity (qualitative information). On the other hand, I took photographs of the contents of their respective refrigerators, which represents information potentially delectable by a 'smart' refrigerator

Next, based on both sources (contents of the refrigerator and qualitative interview, I did a personalised simulation, for their personal information. The report was sent, without priof notification, to the users from the account yoursmartfridgee gmail.com, and the message was signed "Your Smart Fridge". The report was written in a 'friendly' language, and the text fonts and colours of the interface design were typically apporiented. Different companies have different characterizations 


\section{London, UK}

Monday - Clear

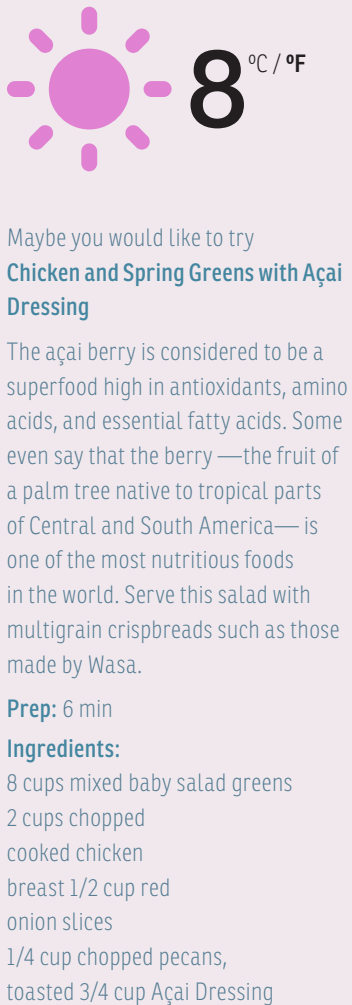

on $84 \%$
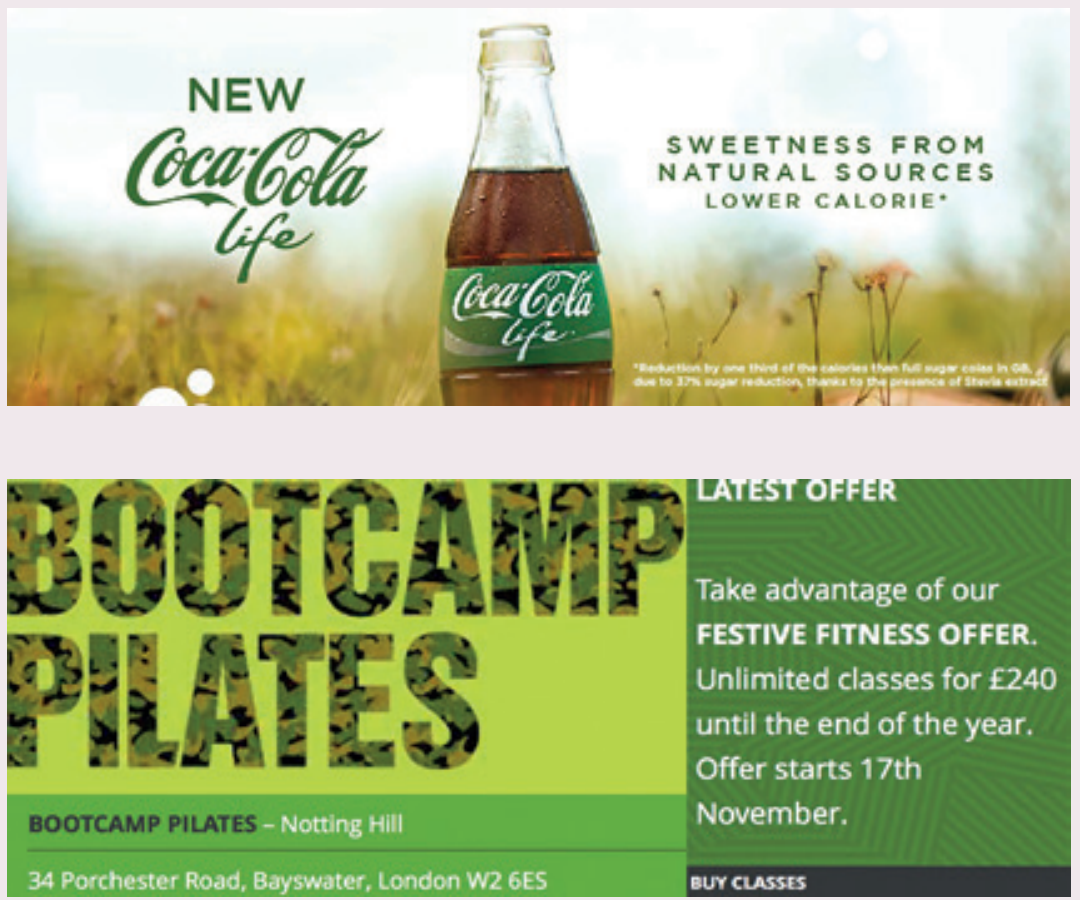

Tal como indica Sterling (2014) en el libro La lucha épica del Internet de las Cosas, Amazon sería una de las cinco grandes empresas involucradas en el negocio del loT. Just as Sterling (2014) indicated in his book The Epic Struggle of the Internet of Things, Amazon would be one of five large firms involved with the loT

冓

MOËT \& CHANDON

TAG YOUR LOVE voces y personalidades. Como refrigerador "inteligente" idoTico, yo interactué con el usuario usando el estilo y los Google, es decir en forma suirt.) Por momentos actue con empleando su clásica actitud de "Hey/ok". En otras ocasiones procuré asimilarme más a Siri, usando una personalidad más amigable, cercana, insinuante y sugestiva. A partir de la actit mecánic usando frases como: "nueve días de un lenguaje «leche baja», «recipiente no identificado», «modo de energía activado» 0 «su refrigerador está funcionando bien». En otras instancias del informe, personificada a la manera de Siri, actue como si entendiera al usuario, hablando en primera persona y diciendo, por ejemplo, "puedo hacer que tu lista de compras se base en tus preferencias", "he juntado tu lista de compras de Amazon" o probablemente estas cansado. Puedo sugens Despué de expras

Despuss de exinteligent" smulación recetas sugeridas información del funcionamiento y productos del refrigerador, publicidad, comentarios relacionados con la pulsera seguidora de actividad (wearables/ activity tracker), además de una lista de compras de Amazon. La elección de incorporar una orden automática de Amazo se debe a que es altamente probable que la empresa esté involucrada en la lista de compras automática de refrigeradores inteligentes. Tal como indica Sterling (2014) en el hibro La luch randes empresas involucias al

\section{"ABUSOS", "SENTIDO" Y "SINSENTIDO"}

Para experimentar con posibles resultados "inteligentes", realicé una simulacion de posibles resultados de Big Data y del servicio de Amazon se llevó a cabo agregando productos que los participantes ya tenían en sus refrigeradores, aplicando la estrategia de productos similares e incorporando los elementos necesarios para preparar las recetas descritas en el mismo reporte. Al interaccionar de manera idIoTica con los usuarios, este punto decid́ íncorporar posibles estrategias de marketing, tes como elegr productos de alto valor y anadh pubicidad. Al componer el reporte tuve que posicionarme en el proceso de toma de decisiones de un refigerador idoTa "intelgente'. Por un lado tenía información cuantitativa proveniente delo observado al abrir el refrigerador de los participantes, esto es datos que potencialmente sus sensores podrían obtener. Por otra parte contaba también con información cualitativa basada en las entrevistas, lo cual me permitio intuir que algunos elementos en el refrigerador hacían poco sentido persona. Con el fin de que el informe del refrigerador hiciera "sentido, utilicé los datos de la entrevista. A un participante estadounidense, por ejemplo, basándome en su propia descripción de su dieta, aś como en el contenido del le propuse, en este caso con un lenguaje Siri, “'por qué no hacer unos brutales macarrones con queso (killer mac ' $n$ ' cheese)?" Luego incorporé la receta en el reporte. and personalities. As an IdloTic 'smart' fridge, I interacted with

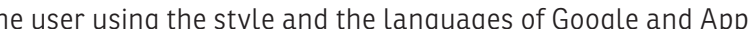
Siri). Actimes I acted as Google, that is, in a succinct, pragmatic and efficient way, using its classic 'Hey/ok' attitude. On other occasions, Itried to assimilate more to Siri, using a friendlier personality, close, suggestive. Based on the Android attitude, was very precise and practical, and used a mechanic language "unidentifed refrigerator is operating correctly". On other instances of the report I personifed the ways of Siri, acting as if I understood the user, speaking in first person and saying things like, "I can make your shopping list based on your preferences", "I've put together your Amazon shopping list" or "You're probably tired. Can I suggest some quick recipes for a Sunday night?'

After examining the different models of 'smart' refrigerators and their services, I decided to include in the simulation suggestions for recipes, information on the operation and products of the refriger ator, publicity, comments related with the aclive tracking wisband, as well as an Amazon order is because it's highty probable that the firm may be involved in the automated shoping list of $s$ art refrigeratos Just as Sterling (2014) indicated in his book The Epic Struggle of the Internet of Things, Amazon would be one of five large firms involved with the loT.

'ABUSES', 'SENSE' AND 'NONSENSE'

To experiment with possible 'smart' results, I did a simulation of possible Big Data and Machine Learning results of a "smart" refrigerator. The Amazon service simulation was done adding products that the participants already had in their refrigerato applying the similar product strategy and incorporating the secessary elements to prepare the recipes described in the same report. As I was interacting in an idlotic manner with the such as choosing high cost products and ad ing pirateges, When wing he report, Ihe to pos process of decisien repor, I ad to position myself in the At this point in the process I relied on two types of information. On the one hand, had guantitative information of what I had observed when opening the participants' refrigerators, that is, data that their sensors could potentially obtain. On the other hand, I had also qualitative information based on the interviews, which allowed me to assume that some items in the refrigerator made little personal sense.

With the airm that the refrigerator report would made sense, I used data from the interview. To a participant from the US, for instance, based on his own description of his diet, as well as from the contents of his refrgerator-which included Siri angers, "why not mate some kilter mac'n this case in incorporated the recipe in the report. 

ados o sinsentido mediante el proceso de descontextualzacion de la información cuantitativa obtenid en el refrigerador

Por ejemplo, cuando examiné el refrigerador de un participante, noté que habia salchichas cubiertas de tocino, lo que contradecia la información obtenida en la entrevista cult litiva, donde el participante señalo tener una dieta me contestó me contestó que no las comia, ya que no le gustaban, y las había dej d r seman fuentes contradictorias de información en la toma de decisión idIoTica usé las salchichas registradas para el pedito de Amazon. Además, a partir de las salchichas realicé la simulación de una correlación "Big Data", cuyo resultado fue agregar chorizo en el pedido.

Luego de que los participantes recibieron la actualización del refrigerador, el proyecto concluyó con una entrevista en profundidad con cada uno de ellos, en la cual analicé los diferentes aspectos explorados en el reporte "inteligente". Esta entrevista cualtativa fue una instancia para hacer preguntas

Las variadas respuestas de los participantes mostraron que estaban conscientes de que a las corporaciones les la estrategia comercial de automatizar compras de productos innecesarios. Todos los participantes observaron el potencia del refrigerador "inteligente" para persuadir a los usuarios con sus sugerencias. Por otra parte, todos los participantes coincidieron en que las empresas tratarán de promocionar empujar sus productos (push products.

CONCLUSIÓN: EL INTERNET DE LAS COSAS

BAJO LA MIRADA DE UN IDIOTA

Los algoritmos modelan el medio ambiente, representan a los seres humanos a través de datos y operan en el ámbito de nuestro comportamiento, ofreciéndonos soluciones

"inteligentes". Los procesos algoritmicos basados en los principios de Machine Learning se estann volviendo más rápidos en el procesamiento de datos. $A$ su vez, grandes conjuntos de

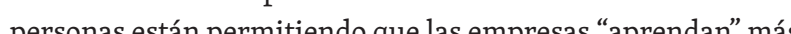
acerca de nosotros. Pero ccómo y qué están “aprendiendo"? En este contexto h prosoción idto " reflexionar, a partir de escenarios posibles, acerca de realidad algorítmica en expansión. Esta figura abre preguntas sobre eventualidades asociadas a este "desarrollo" tecnológico.

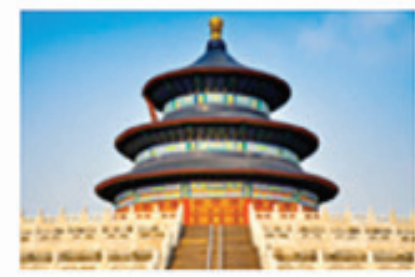

London, Heathrow Airport $\rightarrow$ Beijing,

Capital International Airport

19 days left

Travel start from 01.01.2015 - 19.06.2015

From $£ 654$ * Round trip Economy clas Economy class of automating product purchases unnecessary. All the

persuade users with their suggestions. On the other hand al pants agreed that the firms will try to promote and push

CONCLUSION: THE INTERNET OF THINGS

Algorithms model the environment, represent human offering us 'smart' solutions. The algorithmic processes based the processing of data. At the same time, large datasests are they 'learning'?

intions .

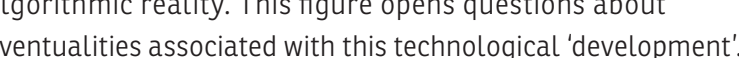

\begin{tabular}{lll}
\hline Detalls > Book > & \\
\hline
\end{tabular}
Elegí como caso de estudio el

refrigerador "inteligente", ya que los

hábitos alimentarios ilustran, tal vez más

que cualquier otra cosa, lo compleja e

impredecible que es la vida humana.

I chose as study case the 'smart'

refrigerator, since eating habits illustrate,

perhaps better than anything else, how

complex and unpredictable human life is.
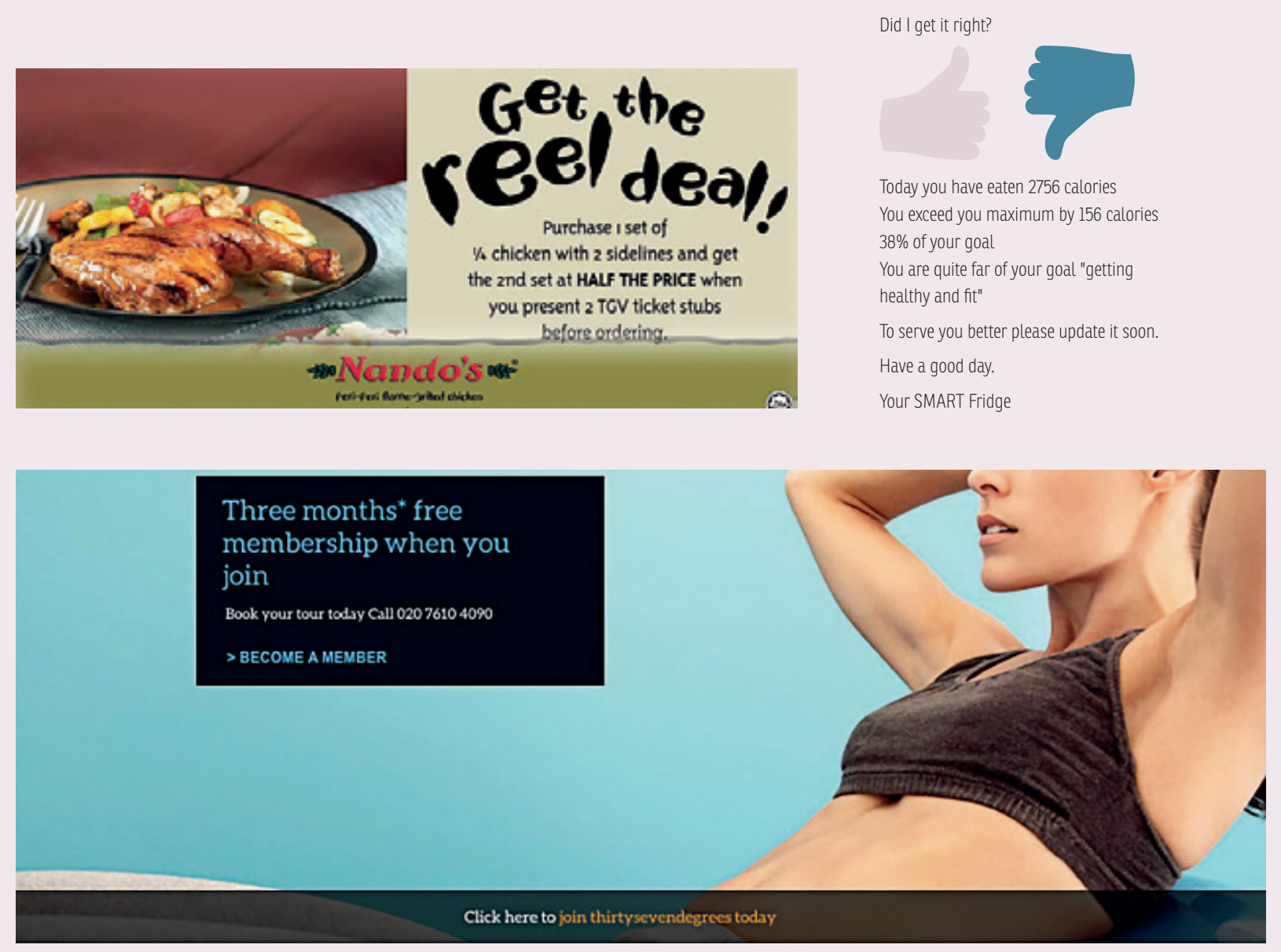

Welcome to thirtysevendegrees Kensington Olympia

Set in the heart of Kensington Olympia. Relax on the roof garden with panoramic views
across west London.

\section{London, UK}

How about a London classic roast

Ingredients:
1.8-2kg chicken
2aarlic cloves, bashed

2 barlic cloves, basted
Sag butter, soffened juice 1 l emon $9^{\circ / / F} \quad$ Precipitation $\ldots 20 \%$

$\approx 83 \%$ they were aware that corporations 'love making users 
El conocimiento producido en esta intervención se destaca por su carácter materializado en el idtoTa, el cual nos fuerza a analizar críticamente la complejidad del contexto algorítmico. lo que declaraba el usuario del refrigerador, sino que cré́ una situación ficticia en la cual levantó información cualitativa y cuantitativa, operando de esta manera como un catalizad de información relevante, permintendo problemat

Tal como indican Tironi y Valderrama (en prensa), la figura idiota pone bajo signo de interrogacion el proyecto tecnodiaria en datos y métricas visulizables, en inuts y outputs automatizados y gestionados algorítmicamente. En efecto, esta investigación, al personificar yo misma la posición del algoritmo, se abrió un espacio para observar problemas que circundan al diseño de la tecnologia del Internet de las Cosa cuestiones que van más allá de la optimización y la eficien Aquí, el idioTa cuestiona activamentelo que está haciendo mientras crea el reporte del refrigerador "inteligente". Al igual que en El idiota de Dostoievski, en este caso se revela I "potencial "corrupción que puede estar operando tras esta Inteligencia aparentemente neutral y objetiva. Este proceso Guattari (1994) hacen del idiota al convertir ol absue Deleuze alto poder del pensamiento y evidenciar posibles abusos. En esta línea la intervención en diseño realizada no solo permitió evidenciar ciertas discontinuidades, sino también levantar proguntas sobre el Internet de las Cosas: Guién está detrás de la puerta de esta interacción y algoritmo "inteligente"?, ¿cuáles son sus incentivos?, ¿empujaría a usuario a conprar productos de mi interes a lestar en la posición de un algoritmo "inteligente"? , itrataria, en e misma posicion, de hacer un uso eficiente de lo que el usuario tenia en el refrigeradon, , me inportaría mostrar

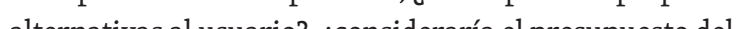
usuario?, sería capaz de preocuparme por la salud del usuario?, ¿cómo lo haría?, ¿cuáles son los valores que se consideran en el proceso de toma de decisiones "inteligentes"?
The knowledge produced in this intervention is notable for its character materialised in the idloT, which forces us to analyse criticalty the complexity of the algorithmic context. This is forted in the fact that the idloTic investigator didn' settle for what the user declared, but created a fictional situation fropating in this manner as a and quanthative information, allowing to probtem the a catalyst of relevant information technological regime.

As pointed out by Tironi and Valderrama (in press), the idiotic figure puts question marks over the techno-intelligent life into visualisable data and metrics, into automated inputs and outputs managed algorithmically. In fact, in this research, my impersonation of the algorithm's position opened a space to observe problems that evolve around designing the Internet of Things technology, questions that go beyond optimization and efficiency

Here, the ido a actively questions what it is doing as it creates the 'smart' refrigerator report. Just as in The Idiot by Dostoievsky, in this case the potential 'corruption' that may be operating benind his 'smartness', apparently neutral and the descristion that Deteuze and Grotaris (1994) rated with idiot, by transforming the absurd into a high power of thought and revealing possible abuses.

In this line, the design intervention performed not only allowed to reveal certain discontinuities, but also to raise questions about the Internet of Things: who is behind the door in this 'smart' interaction and algorithm? What are their incentives? Would I push the user to buy products of my interest If I were in the position of a 'smart' algorithm? Would I try, in the same position, to make an efficient use of what the user had in the refrigerator? Would $I$ mind showing the transparency of t onsider the budget of the wer? Would be capabse would for the user's health? How would I do it? What are the values that are taken into consideration in the process of 'smart' decision making?

\section{DELFINA FANTINI VAN DITMAR}

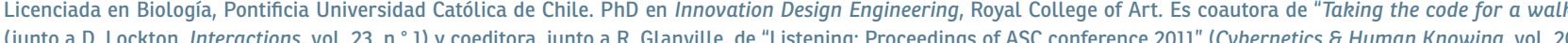
(junto d. L.Lechon,

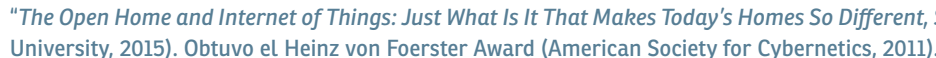

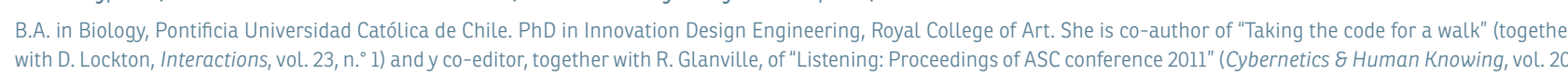

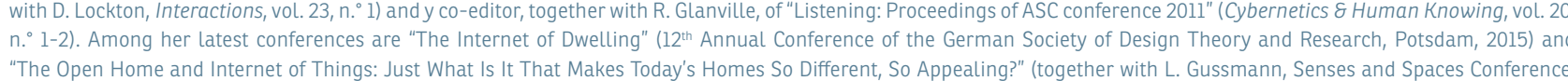

En esta investigación, el idioTa pone en evidencia las estandarizaciones y homogeneizaciones que ocurren humano. En el acelerado mundo de la cultura tecnológica generada principalmente por Silicon Valley (jun a sus imperativos comerciales), muchas de estas investigaciones algorítmicas están basadas en usuarios nodelos que quieren ser smart.

El idioTa rompe con la funcionalidad establecida por el mercado del diseño de productos "inteligentes", con

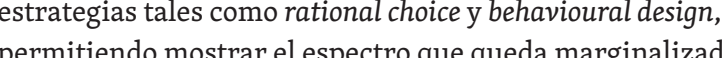
y la complejidad de la vida diaria. De esta forma, la figura del idroTa, que por su estupidez problematiza ese escenario posibilita el preguntarse por ese sujeto. ¿ $\mathrm{P}$ or qué todos tenemos que ser así? ¿Por qué es esa la decisión más óptima? ¿Por qué tenemos que fijarnos en eso? ¿Es necesario?

\section{La investigación en diseño ofrece nuevos enfoques}

Ledologicos para involucrarse con estudios de sistemas algorítmicos, en los cuales el cuestionar el proceso de la investigación en sí, así como la tecnología que se utiliza, es importante y necesario. En este contexto de algoritmizació de nuestras vidas se provocó un cambio de perspectiva

(15) del "progreso" tecnológico, permitiendo observar cómo la lógica algorítmica presenta una serie de controversias acerca de la aparente neutralidad de su "inteligencia".
In this investigation, the idloT reveals the standardisations and homogenisations that occur when adding 'smart' (gorthmics to human behaviour. In the fast-paced world of lechnotogical culture generated mainly from Silicon Valley (along with their commercial imperatives), many of these to be 'smart'. There choice and behaviourat design, with strategies like rational spectrum and the complexity of daily life to be seen. In this way. the figure of the idlot, who for his stupidity problematises this scenario, allows us to question this subject. Why do we all have to be like that? Why is that the best choice? Why do we have to care about that? Is it necessary?

Design research offers new methodologic approaches to get and necessary to of algorithmic systems, in which it's important as the technology used. In this context of algorithmisation of our lives, a change in perspective was caused through a design intervention characterised by the idloTic process of slowing down the speed of the responses of technological 'progress', controversies about the apparent neutrality of its 'smartness'

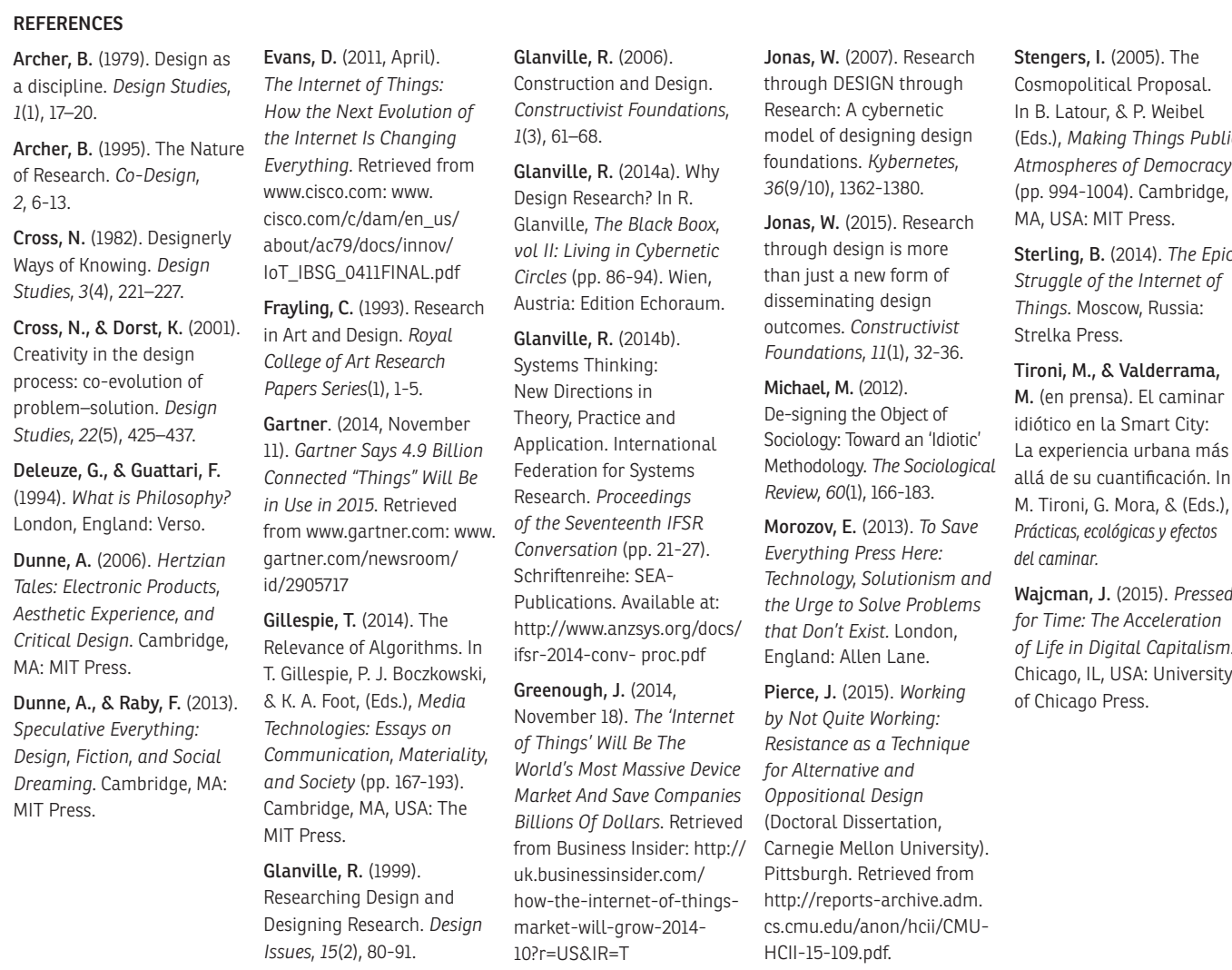

